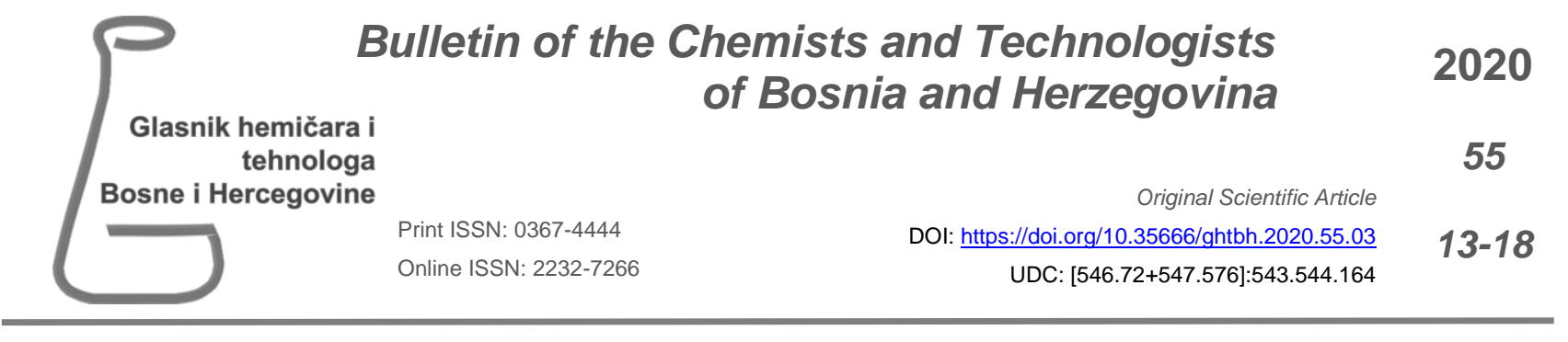

\title{
Synthesis and characterization of Fe(III) complex with thiosemicarbazide-based ligand
}

\author{
Ljubijankić N. ${ }^{a}$, Galijašević S. b* $^{*}$ \\ ${ }^{a}$ Faculty of Science, Department of Chemistry, Zmaja od Bosne 33-35, Sarajevo, Bosnia and Herzegovina \\ ${ }^{\mathrm{b}}$ School of Science and Technology, Sarajevo Medical School, Department of Medical Chemistry and Biochemistry, \\ Hrasnička cesta 3b, Sarajevo, Bosnia and Herzegovina
}

\section{Article info \\ Received: 28/08/2020 \\ Accepted: 15/09/2020}

\section{Keywords: \\ Salicylaldehyde thiosemicarbazone iron-thiosemicarbazone complex antioxidant activity FT-IR}

\section{*Corresponding author:}

Semira Galijašević

E-mail: semira.galijasevic@ssst.edu.ba Phone: 00 387-62-410-878

\begin{abstract}
Complex iron(III) salicylaldehyde thiosemicarbazone with a formula $\mathrm{Na}\left[\mathrm{Fe}(\mathrm{STSC})_{2}\right]$ have been synthesized. Ligand, salicylaldehyde thiosemicarbazone (SCT) was prepared through the condensation reaction of salycilaldehide with thiosemicarbazide. $\mathrm{Na}\left[\mathrm{Fe}(\mathrm{STSC})_{2}\right]$ has been synthesized by reacting $\mathrm{FeCl}_{3}$ with thiosemicarbazide based ligand bearing ONS donor atoms. Complex has been formulated and characterized by mass spectrometry, infrared and UV/visible spectroscopy. The facts showed the formation of a complex in metal:ligand stoichiometric ratio $1: 2$. The ligand is coordinated as an ONS tridentate dianion via oxygen atom after the deprotonation of the phenolic $\mathrm{OH}$-group, azomethine nitrogen and sulphur in thiol form of the deprotonated thiosemicarbazide residue. Antioxidant activity was determined, where ligand showed significant activity, while complex, at low concentration, exhibited almost no activity.
\end{abstract}

\section{INTRODUCTION}

Thiosemicarbazones have been a focus of a research for a long time due to its biological activities. These compounds and its derivatives showed antiviral, antibacterial and antineoplastic effects with different levels of activity. Moreover, the complexes of thiosemicarbazone with metals showed significant biological activity especially due to the changed lipophilicity that allows better deposition in the cell. This is due to their redox properties and lately discovered mechanism of action that involves the Fenton chemistry in the cases of an ironthiosemicarbazone complexes. As a result, the production of free radicals, especially reactive oxygen species (ROS) is increased that in turn leads to the antiproliferative effect. In addition, if thiosemicarbazone are used alone as an active substances, they can sequester iron ions from the cell by chelation mechanism that will cause the inhibition of compounds with an iron in the structure such as heme containing enzymes of iron-protein compounds.<smiles>[R]C([R])=NN([R])C(=S)N([R])[R]</smiles>

Figure 1.General structure of thiosemicarbazones where $\mathrm{X}$ represents sulfur atom while $R_{1}, R_{2}$ and $R_{3}$ represents alkyl or aryl groups.

Anti-tumor activity of thiosemicarbazone complexes have been explained by mechanism that involves depletion of iron from the tumor cells first and formation of $\mathrm{Fe}$ (III) complex. Due to the number of cellular reductant and oxidant, redox turnover between $\mathrm{Fe}$ (III) and $\mathrm{Fe}(\mathrm{II})$ complexes occurs. During this process, in the case of iron complexes, Fenton reaction produces ROS that are damaging tumor DNA bases resulting in cytotoxicity and destruction of tumor cells (Alcaraz, Muñiz, Cavia, et al. 2020). 


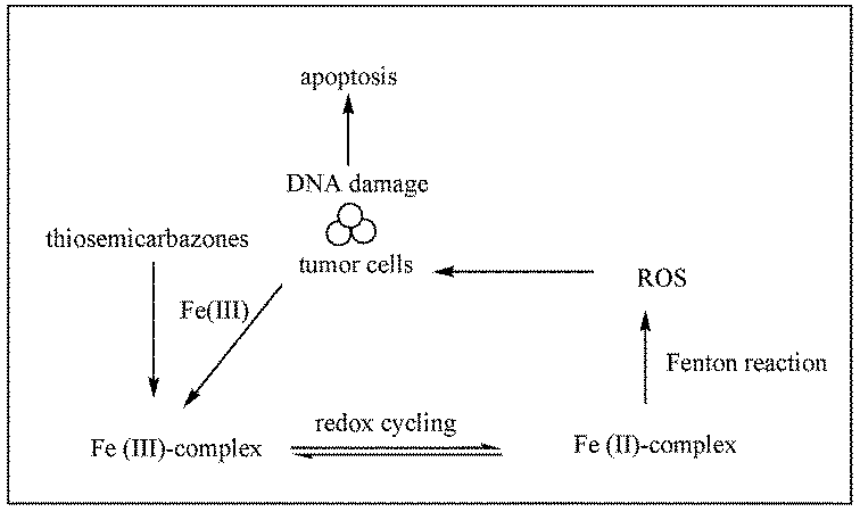

Figure 2. Cytotoxicity mechanism

Besides iron complexes showing antitumor activities, some copper(II) complexes of 3-etoxy-2oxobutyraledehyde-bis(thiosemicarbazone) showed a strong antitumor activity in animal studies. Further studies proved that variation in a ligand structure of these complexes significantly affected the cytotoxic effect. Wide spectrum of anti-microbial effects was detected for the different thiosemicarbazone with complexes with metals. Generally, complexes showed strong activity against Staphylococcus aureus, Neisseria meningitidis, while poor activity against the gramnegative bacilli (Dobek, Klayman, Dickson et al. 1989). In these cases, mechanism of the action of the complexes was explained by electron transfer and free radical activity against microbes. Other potent effects that thiosemicarbazone includes are anticonvulsant activity and antiviral activity either as a ligand or in the complex with a various metals. A recent study found that pyridyl thiosemicarbazones are highly potent agents for the treatment of malaria. Generally, standard compounds used for the treatment such as chloroquine showed the interaction with parasitic heme resulting in a pH-dependent decomposition of the heme (Chou, Chevli Fitch, 1980; Slater, Cerami, 1992; Dorn, Vippagunta, Matile et al.,1998). Thiosemicarbazones derived from phenolic aldehydes showed similar antimalarial activity, based on its ability to chelate iron. Clearly, the synthesis and the investigation of the thiosemicarbazone complexes with metals, especially with iron justify the research in order to detect exact mechanism of it activity and potency in biological systems. In this study, we synthesized and characterized iron(III) salicylaldehyde thiosemicarbazone complex and tested their antioxidant activity.

\section{EXPERIMENTAL}

\section{Material}

All chemical used in the study were obtained from Sigma Aldrich and Merck. Commercial reagents of analytical reagent grade were used without further purifications. Solvents used in the synthesis of the ligand and their complex were distilled before use.

\section{Methods}

ESI ToF MS were obtained on 6210 Time-of-Flight LC/MS instrument (Agilent Technologies, California, USA) connected with Agilent 1200 Series HPLC instrument (Agilent Technologies, Waldbronn, Germany), Instrument consisted of degasser, binary pump, autosampler, column compartment with ZDV (zero dead volume) cell and diode-array detectors (DAD). The mobile phase consists of $0.2 \%$ formic acid in water $(\mathrm{v} / \mathrm{v})(\mathrm{A})$ and acetonitrile $(\mathrm{B})$ in a $1: 1$ ratio. Flow mobile phase is $0.20 \mathrm{~mL} / \mathrm{min}$, column compartment temperature $25^{\circ} \mathrm{C}$, and injection volume of samples $\mathrm{c} \approx 1 \mathrm{mg} / \mathrm{mL} 5 \mu \mathrm{L}$. Peak spectral data were stored in the range $190-450 \mathrm{~nm}$. Mass spectra were recorded in the range of $100-2000 \mathrm{~m} / \mathrm{z}$ in negative ESI ionization mode (capillary voltage $4000 \mathrm{~V}$, fragment voltage $140 \mathrm{~V}$, skimmer voltage $60 \mathrm{~V}$, OCT RF voltage $250 \mathrm{~V}$ ); spray gas (nitrogen): pressure 45 psi, temperature $350^{\circ} \mathrm{C}$, flow $12 \mathrm{~L} / \mathrm{min}$.

FTIR spectra were recorded using $\mathrm{KBr}$ pellets on a Perkin Elmer spectrum BX FTIR System in the region $4000-400 \mathrm{~cm}^{-1}$.

The electronic absorption spectra from $200 \mathrm{~nm}$ to 7000 $\mathrm{nm}$ were recorded with Thermo Scientific Multiscan Go using quartz cuvettes with a $1 \mathrm{~cm}$ path length.

Antioxidant capacity of the ligand and a complex was tested by e-BQC lab instrument (bioquochem, CEEI Parque Tecnológico de Asturiasis) based on a redox potential of the tested compounds and its comparison with antioxidant activity of ascorbic acid. Measurements are expressed in charge units- microCoulombs $(\mu \mathrm{C})$. To compare the results $(\mu \mathrm{C})$ to antioxidant capacity units of Vitamin $\mathrm{C}$ Antioxidant Capacity Equivalents (CEAC) are used. Briefly, calibration curve with a standard solution of ascorbic acid diluted in a standard buffer solution was used to measure charge values $(\mu \mathrm{C})$. Regression line was used to obtain the equation: Charge value $(\mu \mathrm{C})=\mathrm{a}$ Concentration $(\mu \mathrm{M})+b$ where measured charge values of a tested solutions were used and converted to concentrations of the tested samples that have equivalent antioxidant capacity as a model antioxidant (CEAC) (Rey, Gómez, Muñoz-Cimadevilla et al, 2018). Ligand and complex were dissolved in a dichloromethane and then diluted with the $150 \mathrm{mM}$ phosphate buffer pH 7.4 in order to minimize the effect of the organic solvent on e-BQC measuring strips.

\section{Synthesis of ligand salicylaldehyde thiosemicarbazone}

The amount of $0.911 \mathrm{~g}$ thiosemicarbazide $(0.01 \mathrm{~mol})$ was dissolved in $75 \mathrm{~mL}$ of warmed distilled water and volume of $1.044 \mathrm{~mL}$ salicylaldehyde $(0.01 \mathrm{~mol})$ was added to the solution. The reaction mixture was refluxed for 5 hours at $55-60^{\circ} \mathrm{C}$. Afterwards, solution was cooled on ice bath and the crystals of white salicylaldehyde thiosemicarbazone were collected by filtration, dried by vacuum pump and recrystallized from ethanol with $75 \%$ yield (Archana, Ezhilarasi, 2012). Ligand is insoluble in water and benzene, soluble in dimethylformamide, dimethyl sulfoxide and dichloromethane. 
White solid; Yield: (75\%). M.p. $250^{\circ} \mathrm{C}$. FT-IR(KBr): v, $\mathrm{cm}^{-1} 1263(\mathrm{C}-\mathrm{O}), 1616 \quad(\mathrm{C}=\mathrm{N}), 777(\mathrm{C}=\mathrm{S}), \quad \mathrm{UV}-\mathrm{Vis}$ (DMF): $\lambda_{\max }, \mathrm{nm} 234,309,334$.

\section{Synthesis of iron(III) salicylaldehyde thiosemicarbazone, $\mathrm{Na}\left[\mathrm{Fe}(\mathrm{STSC})_{2}\right]$}

The amount of $0.135 \mathrm{~g}$ of iron (III) chloride $\left(\mathrm{FeCl}_{3} \cdot 6 \mathrm{H}_{2} \mathrm{O}\right)(0.0005 \mathrm{~mol})$ was dissolved in $15 \mathrm{~mL}$ of slightly warmed methanol and mixed with $0.204 \mathrm{~g}$ $(0.0015 \mathrm{~mol})$ of sodium acetate three hydrate $(\mathrm{NaOAc}$. $3 \mathrm{H}_{2} \mathrm{O}$ ). After cooling to room temperature, the solution was filtered and ligand, salicylaldehyde thiosemicarbazone $(0.195 \mathrm{~g}, 0.001 \mathrm{~mol})$ was added. The mixture was gently heated at $45-50{ }^{\circ} \mathrm{C}$ for about 30 minutes with continuous stirring. After the mixture was cooled to a room temperature, separation of the solid was observed. The mixture was left at room temperature over the next 24 hours resulting in complete precipitation of a black solid. Subsequently, the obtained complex was filtered, the crystals washed with methanol and ether and dried in a vacuum desiccators (Semanti, Rama, Falgun et al., 2010; Sulekh, Lokesh, 2005).

Insoluble in water, benzene, soluble in dimethylformamide, dimethyl sulfoxide and dichloromethane.

Black solid; Yield: (71\%). M.p. $227^{\circ} \mathrm{C}$. FT-IR (KBr): v, $\mathrm{cm}^{-1} 11304(\mathrm{C}-\mathrm{O}), 1603(\mathrm{C}=\mathrm{N}), 737(\mathrm{C}-\mathrm{S}), 590(\mathrm{Fe}-\mathrm{N})$,
457 (Fe-O), 427 (Fe-S); UV-Vis (DMF): $\lambda_{\max }, \mathrm{nm} \mathrm{238,}$ 308, 337. ESI ToF $\mathrm{m} / \mathrm{z}=441.99746[\mathrm{M}+\mathrm{H}]^{+}$

\section{RESULTS AND DISCUSSION}

Ligand salicylaldehyde thiosemicarbazone and a complex iron(III) salicylaldehyde thiosemicarbazone were synthesized from the starting compound thiosemicarbazide by modified synthesis procedures. Complex was synthesizes in the presence of sodium acetate three hydrate with the addition of $\mathrm{FeCl}_{3} \cdot 6 \mathrm{H}_{2} \mathrm{O}$ (Figures 3 and 4).

Obtained ligand and a complex were insoluble in the water, benzene or chloroform, but soluble in the dimethylformamide, dimethylsulfoxide and dichloromethane. Synthesized compounds were characterized by UV/Visible spectroscopy and FT-IR. Mass spectroscopy confirming the presence of a newly formed complex.

ESI ToF mass spectrometry confirmed existence of $\left[\mathrm{C}_{16} \mathrm{H}_{14} \mathrm{~N}_{6} \mathrm{O}_{2} \mathrm{~S}_{2} \mathrm{Fe}\right]^{-}$, ion with $\mathrm{m} / \mathrm{z}$ values at 441.99746 amu. Spectra showed a series of peaks at 199.8; 194.039; $318.901 ; 640.8082$ that are corresponding to the various fragments (Figure 5).

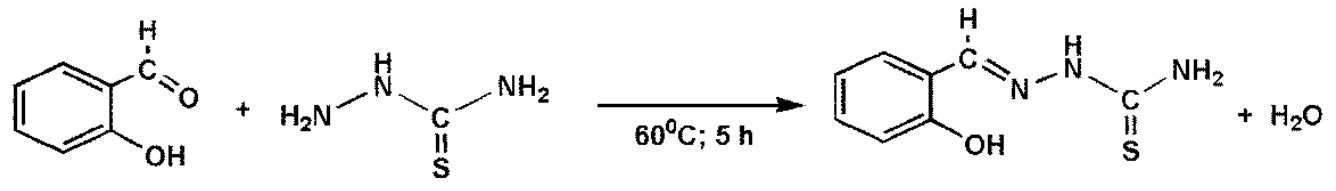

Chemical Formula: $\mathrm{C}_{7} \mathrm{H}_{6} \mathrm{O}_{2}$ Molecular Weight: 122,12
Chemical Formula: $\mathrm{CH}_{5} \mathrm{~N}_{3} \mathrm{~S}$ Molecular Weight: 91,14
Chemical Form ula: $\mathrm{C}_{8} \mathrm{H}_{9} \mathrm{~N}_{3} \mathrm{OS}$ Molecular Weight: 195,24

Figure 3. Ligand synthesis, thiosemicarbazone salicylaldehyde (STSC)

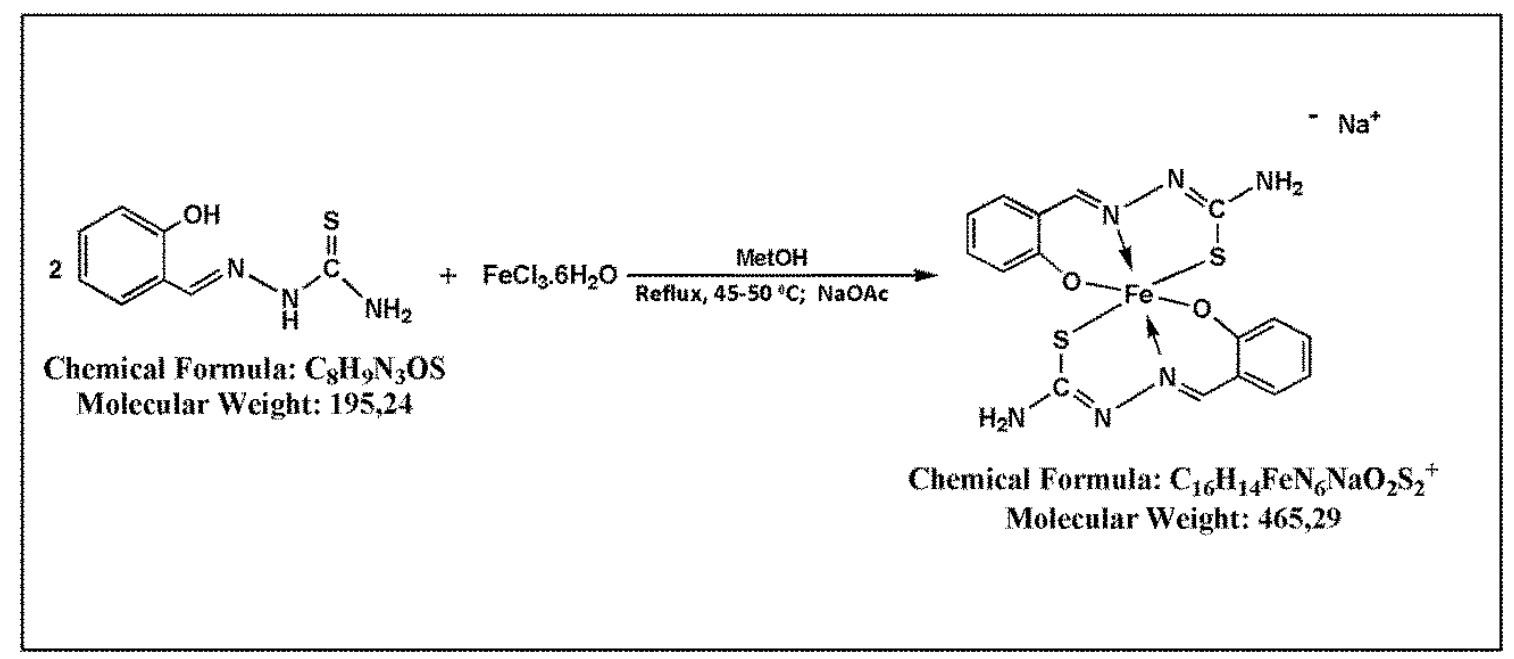

Figure 4. Synthesis of iron(III) complex with salicylaldehyde thiosemicarbazone, $\mathrm{Na}\left[\mathrm{Fe}(\mathrm{STSC})_{2}\right]$ 


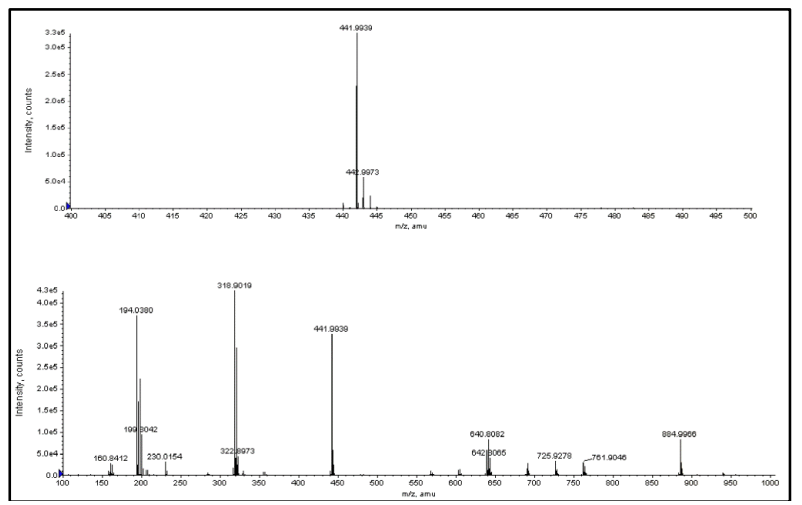

Figure 5.Mass spectrum of $\mathrm{Na}$ [Fe (STSC) 2]
Table 1. Calculated and experimental mass spectra data for the molecular ion

\begin{tabular}{l|l}
\hline Molecular ion & $\mathrm{C}_{16} \mathrm{H}_{14} \mathrm{~N}_{6} \mathrm{O}_{2} \mathrm{~S}_{2} \mathrm{Fe}^{-}$ \\
\hline Theoretical mass & 441.99746 \\
\hline Experimental mass & 441.99775 \\
\hline Error in mass $/ m D a$ & 0.29458 \\
\hline Error in mass/ppm & 0.67 \\
\hline
\end{tabular}

IR spectra were recorded for the ligand and a complex in the region of 2300 to $400 \mathrm{~cm}^{-1}$, analyzed and the assignment of the detected frequencies have been compared with the literature values for the specific group vibrations. The Table 2 shows the assigned values for the ligand and the complex.

Table 2. FT-IR data for the ligand and complex (2300 to $400 \mathrm{~cm}^{-1}$ )

\begin{tabular}{|c|c|c|c|c|c|c|c|}
\hline Peak assignment & $\begin{array}{c}\mathbf{v}(\mathrm{C}=\mathrm{N}) \\
\mathrm{cm}^{-1}\end{array}$ & $\begin{array}{c}\mathbf{v}(\mathrm{C}-\mathrm{O}) \\
\mathrm{cm}^{-1}\end{array}$ & $\begin{array}{c}v(C=S) \\
\mathrm{cm}^{-1}\end{array}$ & $\begin{array}{c}v(C-S) \\
\mathrm{cm}^{-1}\end{array}$ & $\begin{array}{c}v(\mathrm{Fe}-\mathrm{N}) \\
\mathrm{cm}^{-1}\end{array}$ & $\begin{array}{c}v(\mathrm{Fe}-\mathrm{O}) \\
\mathrm{cm}^{-1}\end{array}$ & $\begin{array}{c}v(\mathrm{Fe}-\mathrm{S}) \\
\mathrm{cm}^{-1}\end{array}$ \\
\hline STSC & 1616 & 1263 & 777 & - & - & - & - \\
\hline $\mathrm{Na}\left[\mathrm{Fe}(\mathrm{STSC})_{2}\right]$ & 1603 & 1304 & - & 737 & 590 & 457 & 427 \\
\hline
\end{tabular}

STSC-salicylaldehyde thiosemicarbazone, $\mathrm{Na}[\mathrm{Fe}(\mathrm{STSC}) 2]$-iron (III) salicylaldehyde thiosemicarbazone

The ligand is coordinated to iron center as a ONS tridentate dianion via oxygen atom after the deprotonation of the phenolic OH-group, azomethine nitrogen and sulphur in thiol form of the deprotonated thiosemicarbazide. This was confirmed by IR spectra: shift of azomethine stretching to lower frequency, shift of $\mathrm{C}-\mathrm{O}(\mathrm{H})$ vibration to higher frequency and disappearance of the vibration of $\mathrm{C}=\mathrm{S}$ double bond in the spectra of the complex (El-Bahnasawy et al., 2014).

In order to analyze the way of ligand coordination to the metal, the most significant infrared spectral frequencies for the metal complex are compared with the frequencies of the free ligand. A band observed at $1616 \mathrm{~cm}^{-1}$ attributed to the azomethine $\mathrm{C}=\mathrm{N}$ stretching frequency of the free ligand where shifted to lower frequency in the spectra of the complex at $1603 \mathrm{~cm}^{-1}$ indicating the coordination through $\mathrm{N}$ atom. Deprotonated phenolic oxygen - strong absorption band in spectra of ligand positioned at $1263 \mathrm{~cm}^{-1}$ after coordination is shifted to $1304 \mathrm{~cm}^{-1}$ (Baiu et al., 2009), which corresponds to forming of weaker $\mathrm{C}-\mathrm{O}(\mathrm{Fe})$ bond comparing to $\mathrm{C}-\mathrm{O}(\mathrm{H})$ and confirms coordination of ligand to $\mathrm{Fe}(\mathrm{III})$ through deprotonated phenolic oxygen. Also, in the IR spectra of ligand, the characteristic vibration of the $(\mathrm{OH})$ band is observed at $3444 \mathrm{~cm}^{-1}$. The absence of this band in the IR spectra of the complex indicates the coordination via the phenolic oxygen (Vojinović- Ješić et al., 2011). The ligand showed band at $777 \mathrm{~cm}^{-1}$ for ligand for the vibration of the $\mathrm{C}=\mathrm{S}$ bond (Wiles et al., 1967; Thangadurai et al., 2001). The $\mathrm{C}=\mathrm{S}$ band was disappeared in the complex (Al-Amiery et al., 2011) and a new band, $\mathrm{C}-\mathrm{S}$ appeared at $737 \mathrm{~cm}^{-1}$.
This confirms that the other coordination site to iron is through thiolate sulphur (Sampath et al., 2016). The new bands at 590, 457 and $427 \mathrm{~cm}^{-1}$ are attributed to $\mathrm{Fe}-\mathrm{N}$, $\mathrm{Fe}-\mathrm{O}$ and $\mathrm{Fe}-\mathrm{S}$ bonds, respectively (El-Bahnasawy et al., 2014) (Figure 6).

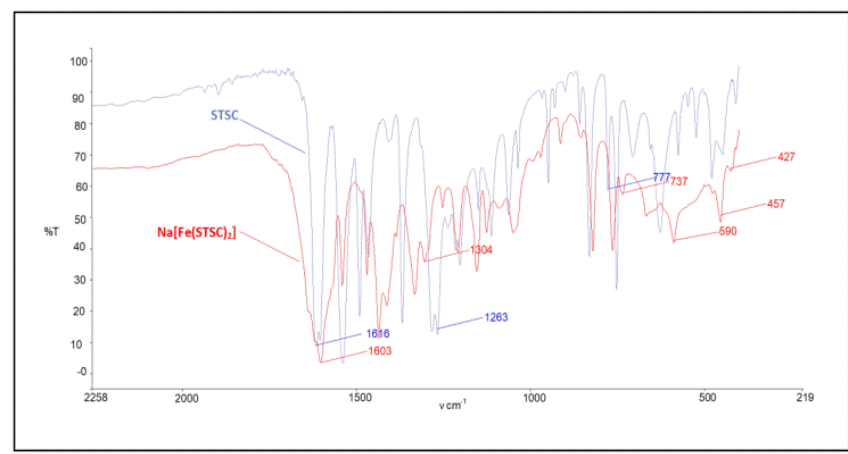

Figure 6. FT-IR spectra of ligand (STSC, blue line) and complex $\left(\mathrm{Na}\left[\mathrm{Fe}(\mathrm{STSC})_{2}\right.\right.$, red line)

UV/Visible spectra were recorded for the ligand and the complex in the range from 220 to $700 \mathrm{~nm}$. Ligand showed maximum peak with higher intensity at $241 \mathrm{~nm}$, peak at $291 \mathrm{~nm}$ and one peak at $345 \mathrm{~nm}$ with a lower intensity. The spectra of the ligand showed characteristic $\pi \rightarrow \pi^{*}$ and $n \rightarrow \pi$ bands due to the substituted benzene group. UV/Vis spectra of the complex showed peaks at $241 \mathrm{~nm}$ and $291 \mathrm{~nm}$, and a shoulder at $345 \mathrm{~nm}$ due to the complexation. 
The d-d transition in this type of complexes usually showed above $500 \mathrm{~nm}$ but in this case, probably to the weak transition was not clearly detected (Figure 7).

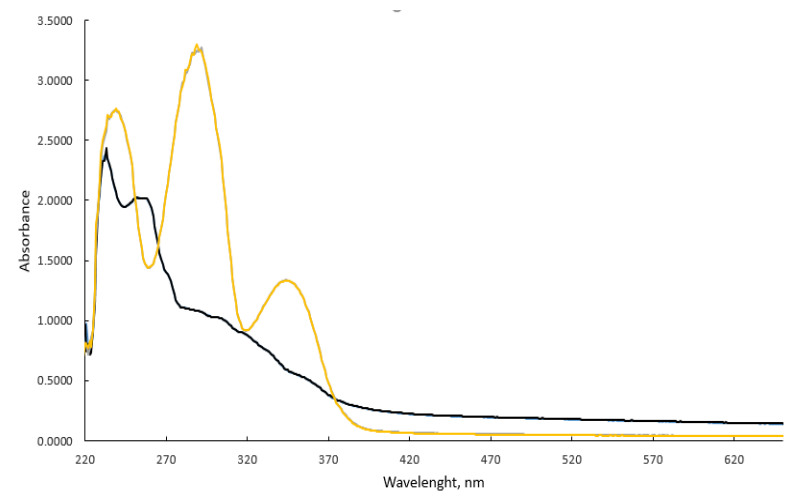

Figure 7. UV/Visible spectra of ligand (yellow line) and a complex (black line)

A number of thiosemicarbazide derivatives have been tested for antioxidant activity and attempts have been made to correlate specific structural features with antioxidant ability of the synthesized compounds based on the thiosemicarbazide structure (Ghosh, Misra, Bhatia et al, 2009). The amine group in thiosemicarbazone moiety significantly contributes to the antioxidant activity of the compound. In addition, phenolic hydroxyl group with its electron donation ability is involved in the increased antioxidant activity. However, complexation with the metal decreases its antioxidant ability due to its involvement into metal coordination process.
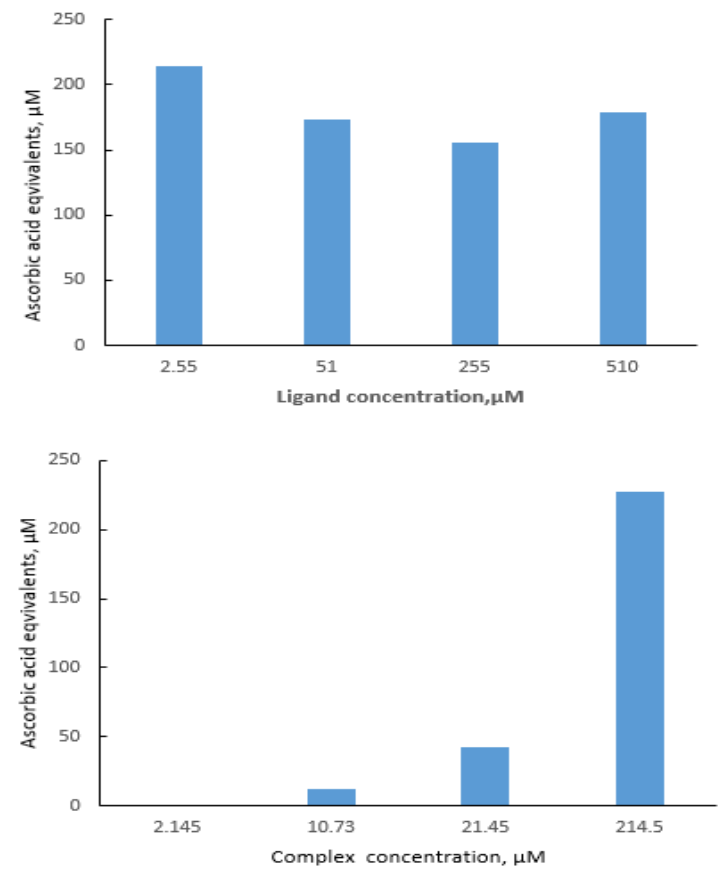

Figure 8. Total antioxidant capacity of a salicylaldehyde thiosemicarbazone (A) and iron(III) salicylaldehyde thiosemicarbazone (B) expressed in ascorbic acid equivalents, $\mu \mathrm{M}$
Salicylaldehyde thiosemicarbazone showed substantial antioxidant capacity that was not dependent on the concentration of the ligand (Figure 8). Iron(III) salicylaldehyde thiosemicarbazone antioxidant activity was almost negligent at the lower micromolar concentration. Only at a high concentration of the complex $(214.5 \mu \mathrm{M})$ a high antioxidant activity was observed that can be attributed only to free amine groups in the structure.

\section{CONCLUSIONS}

We synthesized and characterized salicylaldehyde thiosemicarbazone ligand and its complex, iron (III) salicylaldehyde thiosemicarbazone. Structures were confirmed by mass spectra, and FT-IR methods and UV/Visible spectra were recorded with characteristic maximum wavelengths. Antioxidant activities that are expected for this type of compounds were measured, where ligand showed a high activity regardless of the tested concentration, while a complex showed significant activity only at the higher concentrations. Further studies should be done in order to correlate specific structural features with antioxidant activity and modulation of it that would allow formation of the stable complex, and at the same time, formation of the stable complex.

\section{REFERENCES}

Al-Amiery A. A., Kadhum A.A.H., Abdulreazak H. and Mohamad A.B. (2012). Antifugal and Antioxidant Activites of Pyrrolidone Thiosemicarbazone Complexes. Bioinorganic Chemistry and Applications, 1-6.

Alcaraz R, Muñiz P, Cavia M, et al. (2020) Thiosemicarbazone-metal complexes exhibiting cytotoxicity in colon cancer cell lines through oxidative stress. J Inorg Biochem.;206:110993.

Archana S., Ezhilarasi Rosaline J.(2012) Synthesis Characterization and Application of Salicylaldehyde Thiosemicarbazone and Its Metal Complexes, International Journal of Research in Chemistry and Environment, Vol. 2 Issue 4;130-148

Baiu S.H., El-Ajaily M.M. and El-Barasi. (2009). Antibacterial Activity of Schiff Base Chelates of Divalent Metal Ions. Asian Journal of Chemistry. 21(1), 5-10

Chou, A.C., Chevli, R, Fitch C.D. (1980) Ferriprotoporphyrin IX fulfills the criteria for identification as the chloroquine receptor of malaria parasites. Biochemistry, 19: 1543-9.

Dobek A.S.; Klayman D.L.; Dickson Jr., E.T.; Scovill J.P.; Tramont E.C.(1980)Inhibition of clinically significant bacterial organisms in vitro by 2 acetylpyridine thiosemicarbazones. Antimicrob. Agents Chemother. 18, 27

Dorn, A., Vippagunta, S.R, Matile, H et al. (1998) An assessment of drug-haematin binding as a mechanism for inhibition of haematinpolymerisation by quinoline anti-malarials. Biochem Pharmacol 1998; 55: 727-36.) 
El-Bahnasawy R. M., Sharaf El-Deen L. M., El-Table A.S., Wahba M. A. and El-Monsef.A. (2014). Electrical Conductivity Of Salicylaldehyde Thiosemicarbazone and its $\mathrm{Pd}(\mathrm{II}), \mathrm{Cu}(\mathrm{II})$ and Ru(III) Complexes. Eur. Chem. Bull, 3(5), 441-446.

Ghosh,S., Misra, AK., Bhatia,G., Khan,MM., Khanna, AK. (2009)Syntheses and evaluation of glucosyl aryl thiosemicarbazide and glucosyl thiosemicarbazone derivatives as antioxidant and anti-dyslipidemic agents.Bioorganic \& Medicinal Chemistry Letters 19 (2), 386-389.

Sapath K. and Jayabalakrishnan C. (2016). Ruthenium(III) Thiosemicarbazone Complexes Synthesis, Characterization, DNA Binding, Antibacterial, In vitro Anticancer and Antioxidant Studies. Journal of Engineerng Chemistry and Fuel, 1(1), 40-53.

Semanti, B., Rama, A., Falguni B., Shie-Ming P., et al.(2010) Iridium assisted S-H and C-H activation of benzaldehyde thiosemicarbazones. Synthesis, structure and electrochemical properties of the resulting complexes. Inorg. Chim. Acta., 363, 28482856

Slater, A.F.G., Cerami, A. (1992) Inhibition by chloroquine of a novel haem polymerase enzyme activity in malaria trophozoites. Nature, 355: 1679.
Sulekh, C. Lokesh, K. Gupta., E.P.R. (2005) Mass, IR, electronic, and magnetic studies on copper(II) complexes of semicarbazones and thiosemicarbazones, Spectrochim. Acta Part A., 61, 269-275 .

Rey, S.,Gómez,E., Muñoz-Cimadevilla, H., Hevia, D., (2018). Fast and Accurate Electrochemical Measurement of Total Antioxidant Capacity as an Alternative to Spectrophotometrical Methods. Biomed J Sci \& Tech Res. 21; 1-3

Thangadurai T.D. and Natarajan K. (2001). Tridentate Schiff base complexes of ruthenium(III) containing ONS/ONO donor atoms and their biocidal activites. Transition Metal Chemistry, 26, 717-722

Vojinović-Ješić LJ. S., Leovac V. M., Lalović M. M., Češljević V.I., JovanovićLj. S., Rodić M. V., Divjaković V. (2011). Transition metal complexes with thiosemicarbazide-based ligands. Part 58. Synthesis, spectral and structural characterization of dioxovanadium(V) complexes with salicyl aldehyde thiosemicarbazone, J. Serb. Chem. Soc. 76 (6), 865 877.

Wiles D.M., Gingras BA, Suprunchuk T. (1967). The $\mathrm{C}=\mathrm{S}$ stretching vibration in the infrared spectra of some thiosemicarbazones. Canadian Journal of Chemistry, 45(5), 469-473.

\section{Summary/Sažetak}

Sintetiziran je kompleks željezo(III) salicilaldehid tiosemikarbazon formule $\mathrm{Na}\left[\mathrm{Fe}(\mathrm{STSC})_{2}\right]$. Ligand (SCT) pripremljen je u reakciji kondenzacije salicilaldehida sa tiosemikarbazidom. $\mathrm{Na}\left[\mathrm{Fe}(\mathrm{STSC})_{2}\right]$ sintetiziran je u reakciji $\mathrm{FeCl}_{3} \mathrm{sa} \mathrm{ligandom}$ na bazi tiosemikarbazida sa ONS donorskim atomima. Kompleks je formulisan i okarakterisan masenom spektrometrijom, infracrvenom i UV/Vis spektroskopijom. Podaci su pokazali formiranje metal:ligand kompleksa u stehiometrijskom odnosu 1:2. Ligand je koordiniran kao ONS tridentatni dianion preko atoma kisika nakon deprotoniranja fenolne OHgrupe, azometinskog atoma azota i atoma sumpora u tiolnom obliku poslije deprotoniranja tiosemikarbazidnog ostatka. Određena je antioksidativna aktivnost, gde ligand pokazuje značajnu aktivnost, dok kompleks u maloj koncentraciji, nije pokazao gotovo nikakvu aktivnost. 